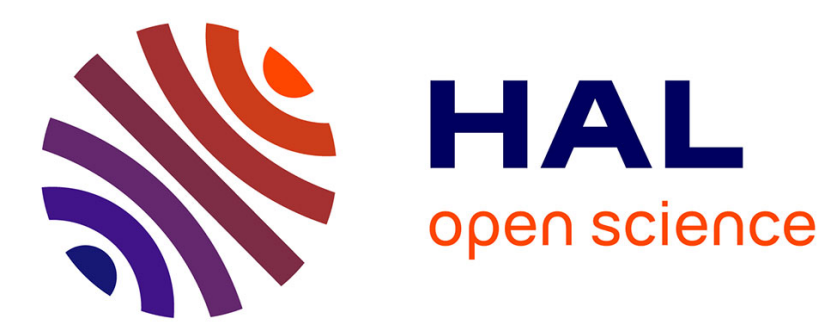

\title{
School Site to Museum Floor: How Informal Science Institutions Work with Schools
}

Justin Dillon

\section{To cite this version:}

Justin Dillon. School Site to Museum Floor: How Informal Science Institutions Work with Schools. International Journal of Science Education, 2007, 29 (12), pp.1489-1507. 10.1080/09500690701494084 . hal-00513353

\section{HAL Id: hal-00513353 \\ https://hal.science/hal-00513353}

Submitted on 1 Sep 2010

HAL is a multi-disciplinary open access archive for the deposit and dissemination of scientific research documents, whether they are published or not. The documents may come from teaching and research institutions in France or abroad, or from public or private research centers.
L'archive ouverte pluridisciplinaire HAL, est destinée au dépôt et à la diffusion de documents scientifiques de niveau recherche, publiés ou non, émanant des établissements d'enseignement et de recherche français ou étrangers, des laboratoires publics ou privés. 


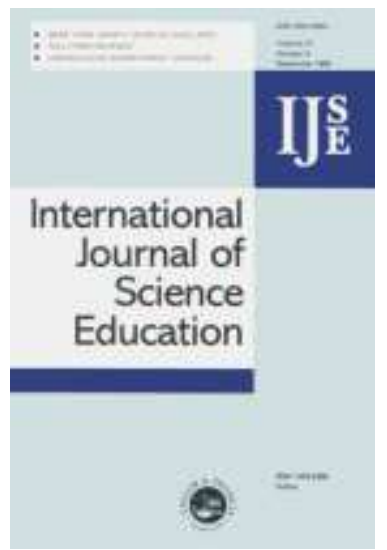

\section{School Site to Museum Floor: How Informal Science Institutions Work with Schools}

\begin{tabular}{|r|l|}
\hline Journal: & International Journal of Science Education \\
\hline Manuscript ID: & TSED-2007-0178 \\
\hline Manuscript Type: & Special Issue Research Paper \\
\hline Keywords: & informal education \\
\hline Keywords (user): & \\
\hline \multicolumn{2}{|l}{} \\
\hline
\end{tabular}

\section{s ScholaroNE" \\ Manuscript Central}




\title{
School Site to Museum Floor:
}

\section{How Informal Science Institutions Work With Schools}

\author{
Michelle Phillips $^{1^{*}}$, Doreen Finkelstein ${ }^{2}, \&$ Saundra Wever-Frerichs ${ }^{3}$ \\ ${ }^{1}$ Inverness Research Associates, USA; ${ }^{2}$ College Board, USA; ${ }^{3}$ King's College London, UK \\ (Received March 2006; revised August 2006; accepted December 2006)
}

Keywords: Informal learning; Science Education; Inquiry-based Science Education; Teacher Professional Development

\begin{abstract}
Two research studies sponsored by CILS investigated the programmes ISIs currently provide to support K-12 science education, particularly in the area of teacher professional development (PD). The first study was a large-scale survey with 475 ISIs responding about the programmes they offer schools and teachers beyond one-day field trips. A large majority of ISIs (73\%) reported having one or more of these programmes, with more than half (59\%) providing one or more forms of teacher PD. ISIs also reported a tendency for their programmes to be under-subscribed, and said funding was the biggest barrier to their ability to provide these programmes.

A second study focused on ISI-based teacher professional development (PD) programmes, looking at whom they serve, how they are funded, and their specific programmatic elements. This study also investigated the extent to which ISI-based PD incorporates features shown to produce measurable effects on teachers' instructional practice. Researchers administered an intensive survey to over 310 ISIs with teacher PD offerings to obtain detail regarding the programming. The findings reported here indicate that the particular promise of ISI-based teacher PD is the potential to incorporate features of PD that research has shown to produce measurable effects on teachers' practice. The results from these two studies suggest that while some opportunities may be missed to leverage the strengths of the ISIs' learning environment in K-12 science education, ISIs continue to support K-12 science education in the US in important and varied ways.
\end{abstract}

\section{Introduction}

Learning in out-of-school settings, often referred to as informal learning, has long been studied for how its attributes and processes differ from learning in schools, often referred to as formal learning (Scribner \& Cole, 1973; Falk, 2001). Literature that addresses learning in museums and informal science institutions (ISIs) such as zoos, aquaria, and nature centres, often describes the opportunities that out-of-school environments offer learners, such as free choice to explore what is meaningful and intrinsically interesting to

*Corresponding author. Email: mphillips07@gmail.com URL: http://mc.manusciptcentral.corm/tsed Email: editor_ijse@hotmail.co.uk 


\section{M.L. Phillips et al.}

them, a collaborative and social learning experience, and authentic experiences using real objects, phenomena, or animals (Falk \& Dierking, 1992; Bitgood, Serrell, \& Thompson, 1994; Hein, 1998).

Museums and informal science institutions (ISIs) are out-of-school learning environments with a history of partnering with schools through field trips and outreach programmes, and more recently, teacher professional development programmes, thereby blending elements of the ISI's less-structured setting with the more structured requirements and goals of the K-12 educational system (Ramey-Gassert, Walberg \& Walberg, 1994; Hofstein \& Rosenfeld, 1996; Inverness Research Associates, 1996; Hein, 2001). An intensive manifestation of this blend is the 'museum-school', where students regularly study in both classroom and museum environments (King, 1998), and where the distinctions between particular learning settings are blurred (Klein et al., 2001) almost to the point of being erased.

Science education reform efforts in the United States have increasingly recognized the importance of incorporating inquiry- and investigation-based learning into school science curricula (NRC, 2000) and have promoted greater use of learner-centered pedagogy and collaborative learning in schools (AAAS 1989, NRC 1999). These are already central features of the ISI learning environment (Falk \& Dierking, 1992; Rennie, Feher, Dierking \& Falk, 2003), therefore, ISIs have the potential to play a key role in K-12 science education reform efforts. Now, more than ever, it is important to understand the realities and nature of ISIs' work with K-12 schools.

The two research studies reported in this paper are surveys of a broad range of ISIs regarding the programmes they offer in support of K-12 science education, and as a result, investigate and document the ways that the learning contexts, resources, and approaches of ISIs are contributing to school-based K-12 learning across the US. Study 1 is primarily an empirical study that documents the current extent of ISIs' involvement with schools and the range and diversity of the educational programmes they offer. Study 2 focuses specifically on K-12 teacher professional development (PD) programmes offered by ISIs. While Study 2 is, in part, an empirical study designed to document the nature and range of ISI-based teacher PD programmes, it is also grounded in the theory, research findings, and literature describing the characteristics and nature of professional development programmes that have been shown to produce a measurable change in teachers' practice. Study 1 and Study 2 are complementary, and coupling the findings of both provides a relatively rich portrait of the numerous and varied ways in which ISIs work with schools.

\section{Study 1}

If informal science institutions (ISIs) can serve important roles in school-based science education through their informal learning contexts, resources, and pedagogy, a critical question is: To what extent are they doing so? Two previous studies have addressed this question. Ten years ago, Inverness Research Associates (1996) conducted a survey of the ISI field and found that at the time, ISIs provided a wide base of support for school science education. The report of the survey findings, An invisible infrastructure: Institutions of informal science education, concluded that informal science institutions do indeed provide infrastructure for science education, contributing in significant ways to the teaching of science in the nation's schools' (p. 18). More recently, the Institute of Museum and Library Services (2002) conducted a survey of museums' programmes for schools and also found a strong connection between museums and K-12 education. However, because IMLS's survey did not differentiate between ISIs and other types of museums, including art and history museums, the reported findings were less illuminating about ISIs or science education specifically. Importantly though, IMLS' survey found that science was one of the content areas least frequently targeted in museums' educational programming (Institute of Museum and Library Services, 2002). 
The first study reported here sought to fill the gap in knowledge about how informal science institutions are currently working with K-12 schools and supporting K-12 science education in the US. The purpose of the study was to document the range and diversity of programmes that are currently being offered by ISIs to serve and support school-based science education, and to identify patterns in how ISIs currently support K-12 education in the US.

\section{Methodology - Study 1}

Development of the ISI database. There is no comprehensive source of all of the names and addresses of every informal science institution (ISI) within the United States, but there are professional organisations that maintain lists of member institutions, and the American Association of Museums (AAM) gathers and publishes contact information for museums and other types of informal learning institutions on an annual basis. These were the main sources researchers used to develop a database of ISIs within the US. Organisation member lists were obtained from the American Association of Botanical Gardens and Arboreta (AABGA), the American Zoo and Aquarium Association (AZA), the Association of Children's Museums (ACM), and the Association of Science-Technology Centres (ASTC). Contact information was taken from the 2004 edition of the 'Official Museum Directory' (American Association of Museums, 2004) for nature centres, organisations self-identified as 'science' institutions (including natural history museums and planetaria), and specialized electricity and technology museums. A final source of contact information for ISIs was personal communication to the research team and networking efforts among museum professionals.

The resulting database included a broad cross-section of many types of ISIs within the US and researchers felt it was acceptably representative of the ISI field. Similar sources and methodologies have been used in other large-scale surveys of the ISI and museum fields (Inverness Research Associates, 1996; American Association of Museums, 2003). However, it is important to note that the majority of the institutions in the database were affiliated in some way with a national professional association, and therefore, it is probable that very small institutions tended to be under-represented (American Association of Museums, 2003). The final database consisted of 2,597 informal science institutions of varied types and sizes, representing all 50 States plus the District of Columbia.

The survey. A six-page survey was developed and mailed to all 2,597 institutions in the ISI database. Institutions were given the choice of responding through the mail or going to a secure web site where they could take the survey on-line. The majority of respondents (72\%) chose to respond through the mail. The ISI was considered to offer support for K-12 science education if the respondent answered 'yes' to the following question: 'Does your institution provide support in the way of programmes, workshops, materials, curricula, etc., for districts, schools, teachers, or students in the broad area of science education besides a one-day field trip'? One-day field trips were excluded from the definition of support in order to identify ISIs with programmes specifically designed for K-12 education as opposed to museum visitors in general. Field trips that included some form of structure and educational support from the ISI, such as classroom activities that precede or follow up the field trip, were included in the definition of support.

Survey questions gathered information on the institution (e.g. ISI's budget size, staff size); the ISI's relationships with K-12 schools and districts (e.g. characteristics of the served schools and districts, school or district funding and support); and the implementation of specific programmes (e.g. type, utilization, and evaluation). The survey included a section of questions that ISIs were asked to answer in terms of one specific, randomly assigned type of programme that they offer for K-12 science education. This random assignment was accomplished through the following steps: (1) A table in the survey listed thirteen types of programmes to serve K-12 science education that were of interest and might be offered by the ISIs. (2) Thirteen different versions of the survey instrument were created, each with one of the thirteen listed 


\section{M.L. Phillips et al.}

programme types in the first position of the table and with the other twelve programme types listed in a random order; different random orders were used on each version. (3) Each ISI was randomly assigned to the survey version they received (identical via mail and on-line for those ISIs that chose to respond over the internet). (4) Instructions in the survey asked ISIs to answer the section of questions in terms of the first programme type in the table that they offered. Responses were double-checked and ISIs that did not correctly follow the instructions $(n=17)$ were removed from the analysis for this section of questions.

This random assignment procedure did not result in exactly equal chances for every programme type to be assigned because thirteen orders were presented rather than every possible order permutation (which was unfeasible). However, the researchers felt that the procedure resulted in an acceptable approximation of true random assignment. The obtained distribution of programme types that ISIs responded about was similar to the obtained distribution of programme types that ISIs said they offered; e.g. teacher special events were $12 \%$ of all programme types offered out of the list, and $13 \%$ of the ISIs answered the section of questions in terms of teacher special events.

The response rate. After an initial mailing and two follow-up mailings, completed surveys were received back from 514 institutions, for an overall response rate of $20 \%$. Of these 514 institutions, 39 did not meet the criteria of an ISI, which left a final data set of 475 ISIs. ${ }^{1}$ These 475 responding ISIs included aquaria, arboreta, botanical gardens, children's museums, natural history museums, nature centres, planetaria, science centres, zoos, and miscellaneous 'other' types of ISIs.

As a method for assessing the degree to which there were systematic differences between responding and non-responding ISIs, ISIs that responded to the first mailing were compared to those that responded to the second and third mailings on six demographic and educational support variables. No differences were found between the three mailings on the following five tested variables: offering support for K-12 science education $\left(\chi^{2}[2]=3.57\right.$, n.s. $)$; size of operating budget $(F[2,299]=.21$, n.s. $)$; annual number of visitors $(F[2,318]=$ .55 , n.s.); number of schools served $(F[2,283=.77$, n.s. $)$; or number of programmes offered $(F[2,472]=$ 1.56 , n.s.). A statistically significant difference $\left(\chi^{2}[2]=6.39, p<.05\right)$ was found for the last tested variable, offering teacher professional development (PD): $64 \%$ of the ISIs that responded to the first mailing offered one or more forms of teacher PD, while this figure dropped to $59 \%$ for the second mailing and to $52 \%$ for the third mailing. Thus the prevalence of offering teacher PD is probably slightly higher in the obtained data set than it is in the ISI field as a whole. These analyses suggest that the findings from the study are probably not strongly skewed by self-selection factors, and that where self-selection factors do play a role, they probably make the data set more inclusive of ISIs that offer K-12 educational support.

\section{Findings - Study 1}

Types of ISI support for K-12 science education. Almost three-fourths of the ISIs in the data set -345 institutions $(73 \%)$ - responded that they 'provide support in the way of programmes, workshops, materials, curricula, etc. for districts, schools, teachers, or students in the broad area of science education besides a oneday field trip'. This demonstrates a very broad base of support for school-based science education that extended across all of the different types of informal science institutions in the data set.

\footnotetext{
${ }^{1}$ The 39 that were removed described themselves as children's museums or miscellaneous 'other' museums with no 'type of collections, exhibits or programmes that focus on any aspect of science, broadly defined'; and/or they did not have a physical, permanent location; and/or they were in development and not yet open to the public or to schools.
} 
Table 1:

Types of Programmes Offered by ISIs

\begin{tabular}{|l|r|r|}
\hline Type of Programme & $\begin{array}{l}\text { \# of } \\
\text { ISIs }\end{array}$ & $\begin{array}{l}\text { \% of } \\
\text { ISIs* }\end{array}$ \\
\hline DIRECT-TO-STUDENT PROGRAMMES & 307 & $65 \%$ \\
\hline $\begin{array}{l}\text { Structured and educationally supported field trips (providing } \\
\text { teachers with activities that precede and/or follow up on their } \\
\text { students' visits to the institution) }\end{array}$ & 259 & $55 \%$ \\
\hline $\begin{array}{l}\text { Outreach programmes (“van” programmes, traveling } \\
\text { demonstrations, support for school science fairs, etc.) }\end{array}$ & 245 & $52 \%$ \\
\hline $\begin{array}{l}\text { TEACHER PROFESSIONAL DEVELOPMENT } \\
\text { PROGRAMMES }\end{array}$ & 279 & $59 \%$ \\
\hline $\begin{array}{l}\text { Teacher special events (one-day workshops or special gatherings } \\
\text { that take place on a single day) }\end{array}$ & 205 & $44 \%$ \\
\hline $\begin{array}{l}\text { Teacher multi-day workshops (professional development events } \\
\text { that last at least 8 hours but less than 40; e.g., a three-day } \\
\text { workshop on a specific topic or a series of five Saturday sessions) }\end{array}$ & 117 & $25 \%$ \\
\hline
\end{tabular}

\footnotetext{
${ }^{2}$ At one point it was hoped that comparisons could be made between this survey's results and the results obtained by Inverness Research Associates (1996) for these programmes, but it proved impossible to match up the two data sets to make meaningful comparisons.
} 


\section{M.L. Phillips et al.}

\begin{tabular}{|l|c|c|}
\hline $\begin{array}{l}\text { Pre-service and formal teacher education connections } \\
\text { (courses, apprenticeships, pre-service observations, and/or } \\
\text { research opportunities for individuals enrolled in teacher } \\
\text { education programmes) }\end{array}$ & 107 & $23 \%$ \\
\hline $\begin{array}{l}\text { Teacher coaching and classroom support (demonstrations, } \\
\text { shared teaching, and/or other forms of in-school support by staff } \\
\text { or teacher interns from your institution) }\end{array}$ & 97 & $21 \%$ \\
\hline $\begin{array}{l}\text { Teacher institutes (professional development experiences, } \\
\text { usually on consecutive days, that cumulatively involve 40 hours } \\
\text { or more of participation) }\end{array}$ & 76 & $16 \%$ \\
\hline $\begin{array}{l}\text { Professional development provider training (training for } \\
\text { administrators or staff providers of teacher professional } \\
\text { development) }\end{array}$ & 70 & $15 \%$ \\
\hline $\begin{array}{l}\text { Teacher internships (teachers working in the museum on a full- } \\
\text { or part-time basis, e.g., a teacher on a special assignment or a } \\
\text { teacher serving as a science specialist for the district) }\end{array}$ & 61 & $13 \%$ \\
\hline COLLABORATIVES AND NATIONAL PROGRAMMES & 217 & $46 \%$ \\
\hline $\begin{array}{l}\text { Collaboratives or partnerships (the institution is a member of } \\
\text { local educational collaboratives, possibly involving schools, } \\
\text { industry, universities, or some combination) }\end{array}$ & 212 & $45 \%$ \\
\hline $\begin{array}{l}\text { National science education programmes (the institution serves } \\
\text { as a base for national-level programmes such as MESA, the } \\
\text { JASON Project, and Challenger Centres, which involve students } \\
\text { and/or their teachers) }\end{array}$ & 38 & $8 \%$ \\
\hline $\begin{array}{l}\text { CLASSROOM MATERIALS AND CURRICULA } \\
\text { PROGRAMMES }\end{array}$ & 199 & $42 \%$ \\
\hline $\begin{array}{l}\text { Materials and kit-based support (support in helping teachers, } \\
\text { schools, or districts select, buy, make, borrow, organize, manage, } \\
\text { replenish, and repair classroom science teaching materials) }\end{array}$ & 153 & $33 \%$ \\
\hline $\begin{array}{l}\text { Curriculum development/support (institutional support for the } \\
\text { development and/or design of curricula, or technical assistance } \\
\text { with selecting curricula) }\end{array}$ & 128 & $27 \%$ \\
\hline TOTAL ISIs WITH AT LEAST ONE PROGRAMME & 345 & $73 \%$ \\
\hline
\end{tabular}

$*$ these percents have a margin of error $(95 \% \mathrm{CI})$ of $\pm 5 \%$.Schools Served by ISIs and Funding Support

The median number of schools served by ISIs was 40 and the median number of districts served was 8 . ISIs overwhelmingly served elementary schools over middle and high schools, with elementary schools averaging $73 \%$ of the total schools served. ISIs also were most likely to serve schools that had underserved students in the school's student population: an average of $44 \%$ of the schools served were described by ISIs as having a 'large number of underserved students, proportional to the region'.

Funding was a major constraint for ISIs. Out of a list of five possible barriers to an ISI's ability to provide support for K-12 educational programmes, the highest ranks were given to the two that dealt with funding at the ISI and school/district level. Lower-ranked barriers were institutional space, school/district policies, and staff training. 
Table 2:

Participant Utilization Across Programme Categories

\begin{tabular}{|l|c|c|}
\hline Programme Category & $\begin{array}{l}\text { \% Can } \\
\text { Handle More } \\
\text { Participants }\end{array}$ & $\begin{array}{l}\text { \% Have to } \\
\text { Turn People } \\
\text { Away }\end{array}$ \\
\hline Direct-to-Student Programmes & $51 \%$ & $31 \%$ \\
\hline $\begin{array}{l}\text { Teacher Professional Development } \\
\text { Programmes }\end{array}$ & $50 \%$ & $18 \%$ \\
\hline $\begin{array}{l}\text { Collaboratives and National } \\
\text { Programmes }\end{array}$ & $50 \%$ & $25 \%$ \\
\hline $\begin{array}{l}\text { Classroom Materials and Curricula } \\
\text { Programmes }\end{array}$ & $62 \%$ & $20 \%$ \\
\hline Total for All Programmes & $53 \%$ & $24 \%$ \\
\hline
\end{tabular}

Methods of programme evaluation. Finally, ISIs were asked about the evaluation methods they use, and were again asked to respond in terms of the randomly assigned programme. ISIs could check off more than one method if multiple methods were used. ISIs reported that $93 \%$ of the programmes were evaluated by some method, either formally or informally. The most common method was to gather feedback about the programme and its effectiveness, either from the participants (90\% of programmes) or from school/district administrators (49\% of programmes). Methods of evaluation that are most useful for accountability requirements in schools - investigation of changes in teacher or student behaviour, teacher or student attitude, and student achievement - were also used, but for less than $25 \%$ of the programmes.

\section{Discussion - Study 1}

The results from Study 1 show that the majority of ISIs play a role in K-12 science education and offer a wide range of programmes designed to support K-12 teachers, as well as students and schools. These results replicate and confirm earlier survey findings from Inverness Research Associates (1996) and the Institute of 


\section{M.L. Phillips et al.}

Museum and Library Services (2002). The most common types of programmes offered by ISIs were those that allowed ISIs to connect their institutional collections and pedagogy directly with students, either at the ISI itself (structured field trips) or through outreach. The least common types of programmes were materials and curriculum support, both of which require the ISI to navigate the constraints of the formal classroom environment. The survey also uncovered some patterns around ISIs and their support for schools, including a tendency to serve elementary schools, difficulties with funding, a problem with under-utilization of programmes, and a lack of outcome measures such as student achievement in programme evaluation.

Overall, these findings suggest that while ISIs are indeed continuing to do substantial work with K-12 science education, there might be a separation between the ISI and school agendas that could account for the under-utilization of programmes. Future research that looks at utilization patterns in more detail would be useful to uncover the reasons behind this finding, particularly studies to look at the teacher, school, and district perspectives on ISI programmes. A final important finding from this study was that more than half of ISIs offered one or more forms of teacher professional development programmes, the focus of Study 2.

\section{Study 2}

For K-12 teachers, ISIs are places where they might access unique resources such as science exhibits, gardens, collections of animals, or scientists' expertise - resources that may not be easily obtained from other sources. ISI staff are often knowledgeable of the most recent developments in science research, as well as how to teach and learn science through hands-on, inquiry-based activities and projects. Due to ISIs' coupling of free-choice learning environments and promotion of the public's understanding of science, ISIs often provide exposure to teaching philosophies and experience with pedagogies distinct from those offered by other teacher professional development (PD) providers (Olson, Cox-Peterson, \& McComas, 2001; RameyGassert, Walberg, \& Walberg, 1994). Thus, ISIs have the potential to be important sources of teacher professional development consistent with and supportive of K-12 district reform efforts in the United States. However, there is scant research on what, exactly, ISIs offer in the way of teacher professional development programmes (Melber \& Cox-Petersen, 2005). There is even less research on the extent to which ISI-based teacher PD programmes are aligned with current science education reform efforts and research on best practices in teacher professional development.

Ultimately, the structure of this study, which involves collecting data from informal science institutions (ISIs) and teachers, addresses the question of whether the features of ISI-based teacher professional development programmes are recognized and valued by teachers, thereby investigating potential factors leading to the under-utilization of ISI-based professional development programmes reported in Study 1. While ISIs continue to invest their resources into the development and provision of teacher professional development programmes in K-12 science, teachers may be selecting other PD programmes with different features that better meet their needs. It is important to understand the features of ISI-based teacher professional development, the extent to which those features are aligned with research in best practices in teacher professional development and teachers' needs.

\section{Methodology - Study 2}

Central questions. This study investigated two central questions:

- What are the design features of ISI-based teacher professional development (PD)?

- To what extent do ISI-based teacher PD programmes integrate particular aspects that we know through research produce measurable effects on teaching practice? 
Surveying the ISIs. All 279 ISIs that reported providing some form of teacher professional development programmes in Study 1 were included in Study 2. An additional 26 ISIs that did not respond to the survey in Study 1 but were nevertheless known to provide teacher professional development were also included, resulting in an initial pool of 305 ISIs for Study 2. A survey was developed by a team of educational researchers, museum educators, programme designers, professional developers, and K-12 science teachers, to solicit more detailed information about these ISIs' professional development programmes. Eight educators from a range of ISIs served as pilot-test respondents for two different versions of the survey. Researchers identified an appropriate survey respondent at each of the 305 ISIs and then mailed them a written letter, asking for their participation in the study, as well as a T-shirt incentive. Three weeks later, the respondents were sent a link to the on-line survey. Follow-up emails were sent at two and four-week intervals to those who had not yet completed the survey. Most respondents reported completing the survey on-line in 30-45 minutes.

Survey précis. The 17-page survey was divided into two halves, each with three sections, for a total of six sections. The first half, or three sections asked respondents to provide detailed contact information (e.g. name/title/email of contact person); provide background information on their professional development programmes in general (e.g. total number of PD programmes offered, which education standards are addressed, if any, how many teachers are served annually); and describe the institution's teacher professional development programme staff (e.g. number of staff that are full time versus part time, number with teaching certificates, number with graduate degrees in science). The last three questions in the first half of the survey were open-ended and asked respondents to describe what they thought was the most important feature of their ISI's teacher PD programmes, what their ISI's teacher PD programmes provide for teachers that other programmes were unable or unlikely to provide, and the biggest challenge their ISI faces in realizing its goals for its teacher PD programmes and why.

The second half of the survey consisted of 22 programme-specific questions, divided into three sections. Respondents were first asked to provide the name of the specific programme they were about to describe and an explanation of why they chose to describe this particular programme. The survey developers made this section of questions programme-specific because they were aware that some ISIs offered more than one teacher PD programme and that respondents' answers to questions such as 'how many hours does each teacher spend in the programme'? or 'how many teachers are served through this PD programme'? might vary across programmes. The three sections asked respondents to provide background information on one specific programme (e.g. number of hours teachers are required to spend, how many events teachers attend, how many teachers are served per year, how long the programme has been offered, the content focus of the programme). The final question of this section consisted of a list of seventeen features or resources that might be included as an element of teacher PD programmes and asked respondents to indicate on a scale how often (always, usually, sometimes, rarely, never, or don't know) each feature was included in this particular PD programme. The remaining two sections asked for information on the K-12 teachers who participate in this PD programme (e.g. their grade level, level of teaching experience, incentives for participating, level of comfort with science); and the evaluation of the PD programme (e.g. who is responsible for evaluation, how often particular aspects of the programme are evaluated, the people who contribute to the evaluation, the purpose of the evaluation).

The final question on the survey asked whether the respondents' ISI had a second teacher PD programme for them to describe. If respondents replied 'yes', the series of 22 programme-specific questions was repeated. If respondents replied 'no', the survey was completed. 


\section{M.L. Phillips et al.}

\section{Findings - Study 2}

The 84 survey respondents described 105 different teacher professional development programmes, for a final response rate of $28 \%$. These respondents came from a variety of informal science institutions (ISIs) with different sizes and purposes, from across the United States, representing science centres, botanical gardens, natural history museums, zoos, aquaria, parks, and research centres. Combined, these 84 ISIs reported providing teacher professional development (PD) programmes for more than 10,000 teachers over the 2004-2005 school year. The survey data provide an overview of the nature of these ISI-based professional development programmes.

Programme features. A list of 17 programme features was developed based on open-ended responses during a series of pilot interviews with museum educators who provide professional development (PD), and based on a review of the literature regarding best practices in professional development. The survey responses, summarized in Table 3, show that each of the 17 features was included in at least one of the PD programmes described by the respondents. Features that respondents described as 'always included' or 'usually included' are reported in Table 3 as 'included' in the ISIs' programme. Features that respondents described as 'rarely included' or 'never included' are reported as 'not included' in their programme.

Table 3:

Features Included In ISI-Based Teacher Professional Development Programmes

\begin{tabular}{|l|l|l|}
\hline Programme feature & Included & $\begin{array}{l}\text { Not } \\
\text { Included }\end{array}$ \\
\hline $\begin{array}{l}\text { Teachers learning science by participating in activities that } \\
\text { they can use in their classroom }\end{array}$ & $88 \%$ & $3 \%$ \\
\hline $\begin{array}{l}\text { Teachers learning how to integrate your institution's } \\
\text { resources into their curriculum }\end{array}$ & $74 \%$ & $11 \%$ \\
\hline Teachers engaging with exhibits & $59 \%$ & $21 \%$ \\
\hline $\begin{array}{l}\text { Web resources sponsored by or affiliated with your } \\
\text { institution }\end{array}$ & $40 \%$ & $45 \%$ \\
\hline Teachers borrowing curriculum kits from your institution & $39 \%$ & $43 \%$ \\
\hline $\begin{array}{l}\text { Teachers learning how to use your institution's curriculum } \\
\text { kits }\end{array}$ & $32 \%$ & $48 \%$ \\
\hline $\begin{array}{l}\text { Educators from your institution performing demonstrations } \\
\text { in participating teachers' classrooms }\end{array}$ & $29 \%$ & $51 \%$ \\
\hline $\begin{array}{l}\text { Educators from your institution providing other forms of } \\
\text { support at participating school sites }\end{array}$ & $28 \%$ & $42 \%$ \\
\hline $\begin{array}{l}\text { Teachers learning science by participating in activities } \\
\text { geared specifically to teachers or adults, so that they } \\
\text { cannot use the activities with their students in their } \\
\text { classrooms }\end{array}$ & $25 \%$ & $56 \%$ \\
\hline $\begin{array}{l}\text { Teachers visiting informal science institutions other than } \\
\text { yours }\end{array}$ & $23 \%$ & $56 \%$ \\
\hline Teachers attending lectures & $22 \%$ & $55 \%$ \\
\hline $\begin{array}{l}\text { Teachers examining and discussing student work with } \\
\text { other teachers }\end{array}$ & $22 \%$ & $56 \%$ \\
\hline
\end{tabular}




\begin{tabular}{|l|l|l|}
\hline $\begin{array}{l}\text { Educators from your institution providing instructional } \\
\text { coaching in participating teachers' classrooms }\end{array}$ & $20 \%$ & $67 \%$ \\
\hline $\begin{array}{l}\text { Teachers providing instructional coaching in other } \\
\text { teachers' classrooms }\end{array}$ & $7 \%$ & $66 \%$ \\
\hline Online discussions among participating teachers & $6 \%$ & $72 \%$ \\
\hline List-serve memberships & $10 \%$ & $73 \%$ \\
\hline Teachers visiting other teachers' classrooms & $3 \%$ & $77 \%$ \\
\hline
\end{tabular}

In general, the teacher professional development programmes provided by ISIs include a combination of features - some of which have been the subject of research in other contexts, and some that are unique to this context. Similarly, there was no single feature common to all the programmes, though an emphasis on teachers' experiences in learning science by participating in activities was a strong theme in most of the programmes. Two features were included in more than two-thirds of the programmes: (1) 'teachers learning science by participating in activities they can use with their students' (88\%), and (2) 'teachers learning how to integrate the ISI's resources into their curriculum' (74\%). The experiential component is emphasized by Darling-Hammond in her description of professional development that is effective in improving teaching (Darling-Hammond, 1998).

Darling-Hammond also suggests that the programme be sustained and intensive over a period of time, and supported by coaching or mentoring (ibid). Overall, $20 \%$ of the ISIs' teacher PD programmes reported that their museum educators provided instructional coaching or mentoring for teachers. In a large-scale study of teachers' reports of effective professional development, Garet and his colleagues found that programmes that included 30 or more contact hours were associated with teachers' reports of increased knowledge and skills (Garet, Porter, Desimone, Birman, \& Yoon, 2001). 35\% of ISIs' teacher PD programmes reported involving 25 or more hours of contact with teachers.

Programme purpose. Respondents were asked, 'Approximately what percentage of this teacher PD programme is focused on each of the following goals: Helping teachers use your institution and/or its resources; Improving teachers' content understanding; Improving teachers' pedagogy or instructional strategies, or other goals'? The possible responses were $0 \%, 1-9 \%, 10-19 \% \ldots 90-99 \%$ or $100 \%$. In this analysis only the first, or primary goal(s) of the programme were examined. Responses were transformed to rank orders (first goal, second goal, or third goal) and equal responses (e.g. two goals ranked at 50-59\%) were given equal ranking. The primary goal of these programmes was most likely to be 'improving teachers' content understanding,' as shown in Figure 4.

Figure 4:

Percentage of ISI-Based Teacher PD Programmes With Particular Primary Goals 


\section{M.L. Phillips et al.}

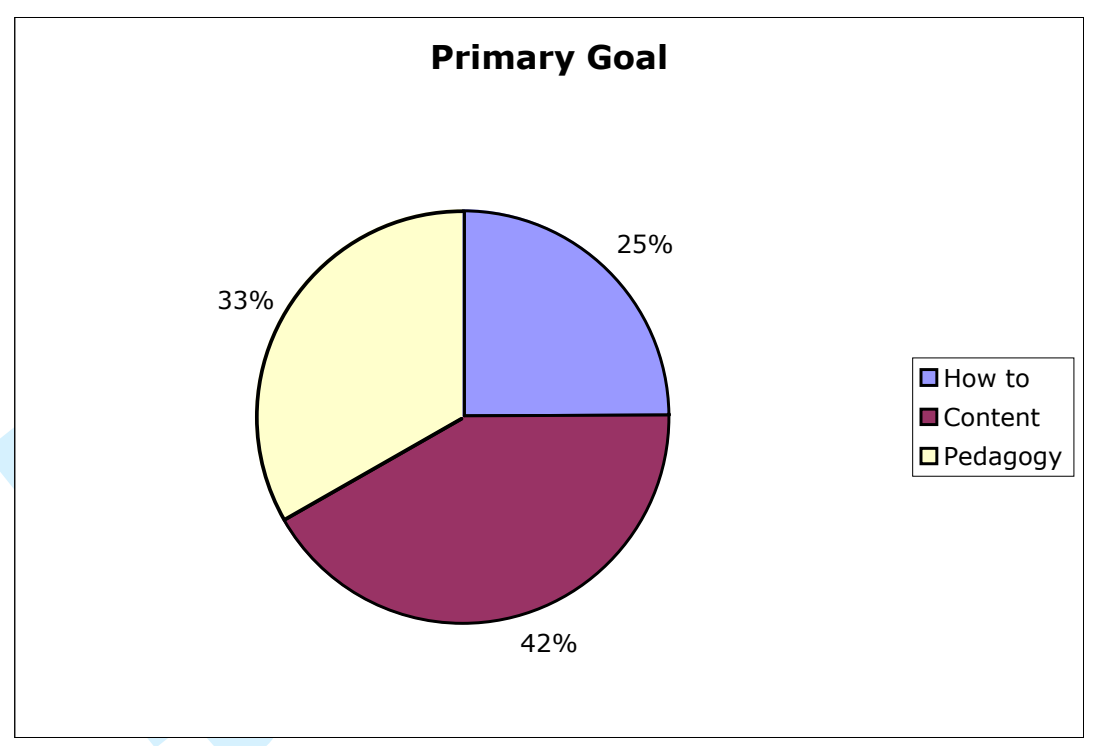

Teachers served. The data show that informal science institutions provide professional development for a large number of teachers. In $40 \%$ of the programmes, these teachers participated in professional development in groups of 25 to 49 teachers. Figure 5 shows the distribution of grade levels served by programmes where the majority (50\% or more) of the teachers served are from a particular grade level, or where the grade level was unpredictable.

Figure 5:

Number of Programmes Serving Teachers From Particular Grade Levels

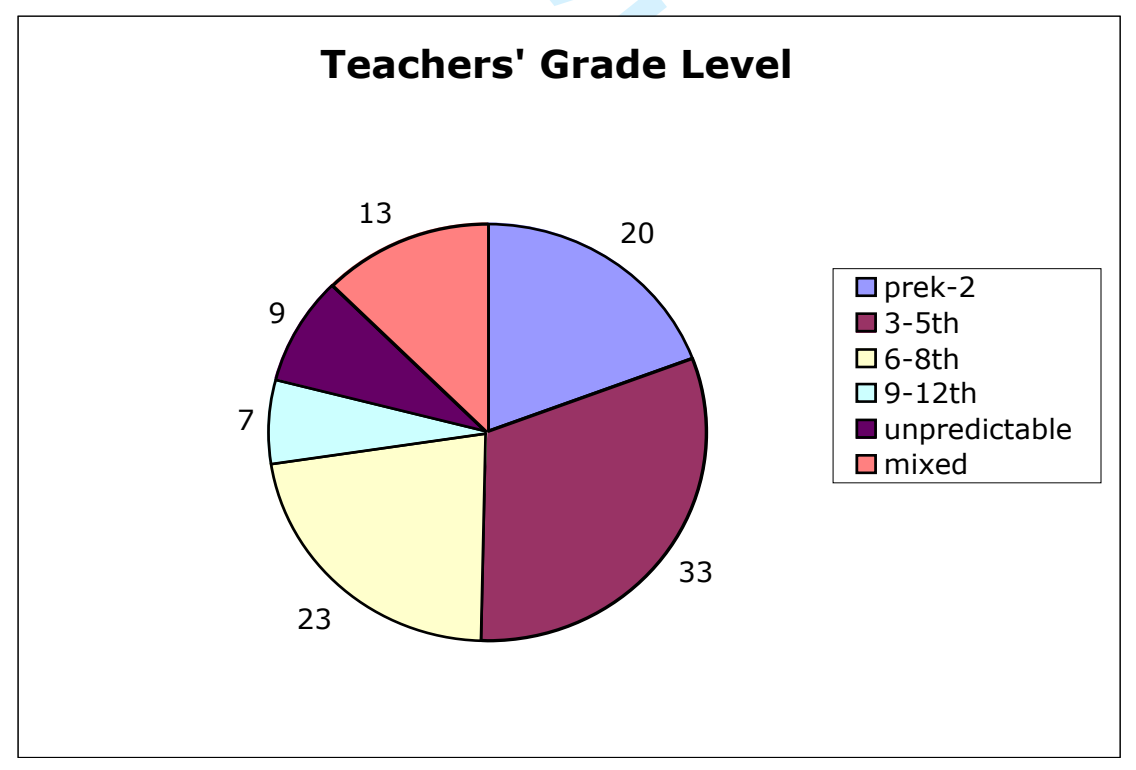

As important as what grade level the PD programmes focused on is that so many of these programmes focused on a particular grade level at all. Focusing on the needs of a particular grade level of teacher may allow these programmes to more effectively meet the unique needs of teachers. Overall, $79 \%$ of the 
programmes focus on teachers of a particular grade level. Of these, most focused on upper elementary level teachers.

Additionally, the survey probed the level of teaching experience of the teachers participating in these professional development programmes.

- 25 respondents said that most (over 50\%) of the teachers participating in their PD programme are 'experienced' teachers (with 5-10 years of teaching experience)

- 17 respondents said that most (over 50\%) of the teachers participating in their PD programme are 'veteran' teachers (with more then 10 years of teaching experience)

- 10 respondents said that most (over 50\%) of the teachers participating in their PD programme are 'novice' teachers (with 1-4 years of teaching experience)

- 6 respondents said that most (over 50\%) of the teachers participating in their PD programme are "preservice' teachers (still preparing to become teachers)

The majority of these programmes serve experienced and veteran teachers; however, it is not clear whether this is a result of institutions targeting these teachers or a result of selection on the part of the teachers who choose to participate. This is an interesting issue and worthy of follow-up, but regardless of the reason why more experienced and veteran teachers turn up for these programmes, this fact alone is likely to have an impact on how the programmes develop, the expectations of the participants, and the types of discussions that occur. Research has shown that reflection and discussion of conceptions of science teaching and learning are effective at developing teacher knowledge and improving practice for novice and experienced teachers (Bell, 1998; Darling-Hammond, 1998; Thompson \& Zeuli, 1999). However, there are distinct differences between the knowledge structures of novices and experts (Barnett \& Hodson, 2001; Meyer, 2004; van Driel, Verloop, $\&$ de Vos, 1998). In general, experts tend to have more accessible and well-structured knowledge and thus, may be able to reflect on their understanding at a deeper level within a professional development programme than novice teachers.

Professional development staff. The traditional qualifications for providing teacher professional development that are recognised by those outside of informal science institutions might be described as expertise in pedagogy or expertise in content. In the survey, respondents were asked how many of the institution's professional development staff hold or have held a K-12 teaching certificate (related to expertise in pedagogy) or graduate degrees in science (related to expertise in content). The overall distribution of these qualifications is shown in Figure 6. These qualifications alone do not necessarily indicate expertise, they simply indicate experience in the areas of pedagogy and content. It should be considered then that this is a limited interpretation of what constitutes qualification. Experience gained from years on the job, practical experience, informal education teaching experience, or specific training courses are not reflected in these responses.

Figure 6:

Percentage of ISI Teacher Professional Development Staff With 'Traditional' Qualifications 


\section{M.L. Phillips et al.}

\section{PD staff overall}
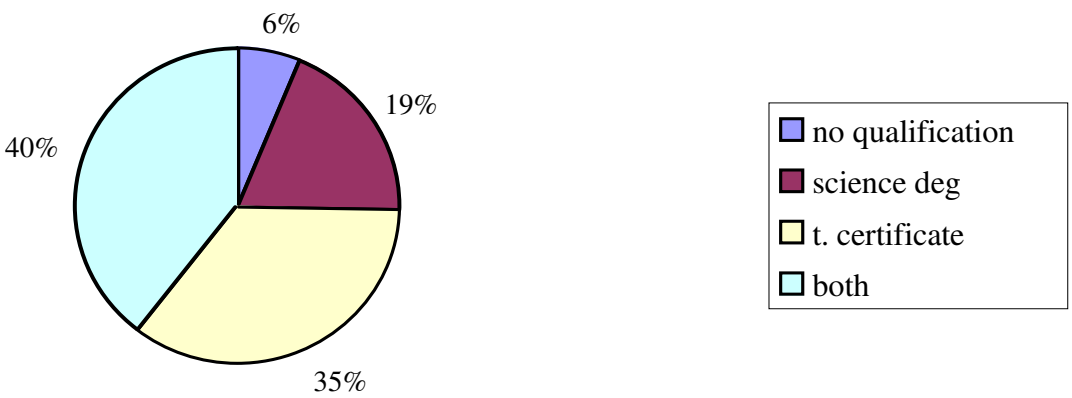

Overall, the qualification most often seen among all the professional development providers was a teaching certificate. $75 \%$ of the programmes have at least one member of their staff who holds (or has held) a teaching certificate while $59 \%$ of the programmes have at least one member of their staff who holds a graduate degree in science. There is a large area of overlap in that $40 \%$ of the programmes have both qualifications represented among their staff. As the size of the programme staff increases, there is a trend toward more of the staff members holding teaching certifications. However, $6 \%$ of the programmes had staff without either a teaching certificate or a graduate degree. Are these programmes run by 'unqualified' staff? To answer this question, these six programmes were examined more closely by considering the respondents' answers to the open-ended questions about the programme. Findings indicate that in each case, the programmes made use of qualifications that were not specifically addressed in the survey. These include:

- A programme that focused solely on how to use the museum, in which years of experience at the institution would provide appropriate expertise.

- A programme that emphasised developing content knowledge and how to use the museum, but for which the focus was not science, but anthropology. The survey did not probe staff qualifications in non-science content areas.

- A programme that sent their staff to receive specific training in professional development.

- A multi-disciplinary programme focusing on botany, writing, and art, which made use of specialists such as scientists, writers, and artists to work with their staff and the teachers.

- A group of programmes that made use of community resources such as the school of education at a local university or members of the local science community who provided lectures.

Thus, there appear to be a wide range of qualifications that the teacher professional development (PD) providers at informal science institutions bring to their programmes, while most of the ISIs still include the traditional qualifications probed in the survey; that is, they have certified teachers or scientists as part of their teacher professional development staff.

\section{Discussion - Study 2}

The results from Study 2 show that the teacher professional development programmes offered by ISIs utilize a combination of features with a particular emphasis on some features that have been found to be effective at changing teachers' practices, such as extended duration ( 25 hours or more) and including 
activities that teachers can use in their classroom. These programmes also include features that are quite unique such as having teachers interact with museum exhibits and integrate ISI resources into their instruction. The primary goal of most of these programmes is to increase teachers' content knowledge, but improving pedagogical knowledge is also important. Overall, these programmes tend to serve experienced and veteran teachers who are prepared for the area in which they are teaching and they primarily focus on the upper elementary grades. These findings suggest that these programmes may not be targeting the teachers who often need the most support in teaching science - those with little scientific experience or preparation for the science classroom (Meyer, 2004; Windschitl, 2004). However, since the survey did not distinguish between ISIs targeting particular teachers and teachers selecting these programmes themselves, another view is possible. These responses could indicate a preference among teachers who have a certain level of confidence (arising from years of experience or a strong science background) in their science instruction, to attend these programmes in order to move their practice on to another level.

The ISI staff who provide this teacher professional development appear to resemble other providers of professional development in that many of them have advanced degrees in science and even more hold or have held teaching certificates. The professional development programmes themselves are also similar to many other PD programmes. Two ways in which they can be distinguished is that they are designed and presented by informal science educators, and that they often take place amid botanical gardens, science exhibitions, nature reserves, and zoos. Notably absent from these programmes are issues related to larger reform efforts within the formal education system, or curriculum adoption and implementation - the foci of many other PD programmes.

The impact of contextualizing professional development in informal learning environments rather than formal classrooms has been the focus of little research. The findings here suggest that further investigations in this area may increase our understanding of several issues. The combination of features that are common to most professional development programmes along with features that are unique to informal science institutions creates a context in which to examine the impact of particular aspects of PD programmes. These programmes also provide opportunities to investigate the PD needs and preferences of experienced teachers. A second phase of this study will investigate these issues in more detail along with issues related to the selection of PD by teachers. It will also shed light on the decision-making processes of designing and implementing teacher professional development by informal science institutions.

\section{Conclusion}

The results from these two studies suggest that while the breadth of ISIs' involvement with schools and the range and diversity of the educational programmes they offer is impressive, ISIs may be missing key opportunities to partner with schools. Study 1 showed that ISIs frequently support students and teachers directly, through the ISIs' collections and pedagogy during field trips and outreach activities. However, it seems that ISIs have yet to determine how best to support students and teachers in terms of the actual curriculum and materials used within the classroom. Some might argue that such support is beyond the purview of the ISI; however, it could also be argued that the learner-centered pedagogy of the ISI learning environment could be easily transferred to the classroom and is a rich potential bridging point between ISI and school science education.

ISIs' not pioneering a route into the classroom may account for some of the under-utilization of ISIs' programmes also reported in Study 1. In addition, while more than half of ISIs offer one or more forms of teacher professional development, these programmes tend to serve experienced teachers at the elementary grade level, a level characterized by a generalized approach to science. Therefore, ISIs may be missing a key 


\section{M.L. Phillips et al.}

opportunity to serve an audience in need - novice teachers at the secondary level, a level characterized by a more specialized approach to science.

The particular promise of teacher professional development programmes offered by ISIs is their potential to incorporate features of PD that research has shown to produce measurable effects on teachers' practice. Study 2 showed that a vast majority of such programmes currently emphasize an experiential approach to teacher learning; that is, teachers are encouraged to participate in activities or experience exhibits in much the same way that their students would. In addition, 35\% of ISIs' teacher PD programmes reported involving 25 or more hours of contact with teachers. While $35 \%$ is not the majority of programmes, it is an impressive number of programmes, considering the paucity of time currently allocated for teacher professional development in general.

While some opportunities may be missed to leverage the strengths of the ISIs' learning environment in K-12 science education, it is clear that ISIs continue to support K-12 science education in the US in important and varied ways. Taken together, these two studies illuminate many of the varied and unique ways in which ISIs work with schools.

\section{Notes on Contributors}

Michelle Phillips was a Senior Researcher at Exploratorium when this research was conducted and the article was written; however, she has since moved and is conducting research and evaluation with Inverness Research Associates in northern California. Doreen Finkelstein was a research associate at Exploratorium when this research was conducted; however, she has since become a research associate at the College Board in New York. Saundra Wever-Frerichs is a doctoral candidate at King's College London. 
References

AAAS (1989). Science for all Americans: A Project 2061 report (No. AAAS Publication Number 89-01S). Washington, DC: AAAS Programme/Committee: Directorate for Edcuation and Human Resources Project 2061.

American Association of Museums (2003). Museum financial information. Washington, DC: American Association of Museums.

American Association of Museums (2004). Official museum directory. New Providence, NJ: National Register Publishing.

Barnett, J., \& Hodson, D. (2001). Pedagogical context knowledge: Toward a fuller understanding of what good science teachers know. Science Education, 85, 426-453.

Bell, B. (1998). Teacher development in science education. In B.J. Fraser \& K.G. Tobin (Eds.), International handbook of science education (pp. 681-693). Norwell, MA: Kluwer Academic Publishers.

Bitgood, S., Serrell, B. \& Thompson, D. (1994). The impact of informal education on visitors to museums. In V. Crane, H. Nicholson, M. Chen \& S. Bitgood (Eds.), Informal science learning (pp. 61-106). Washington, DC: Research Communications Ltd.

Darling-Hammond, L. (1998). Teacher learning that supports student learning. Educational Leadership, 55(5), 6-11.

Falk, J.H. (2001). Free-choice science learning: Framing the discussion. In J. H. Falk (Ed.), Free-choice science education: How we learn science outside of school (pp. 3-20). New York: Teachers College Press.

Falk, J.H. \& Dierking, L. (1992). The museum experience. Washington, D.C.: Whalesback.

Garet, M. S., Porter, A. C., Desimone, L., Birman, B. F., \& Yoon, K. S. (2001). What makes professional development effective? Results from a national sample of teachers. American Educational Research Journal, 38(4), 915-945.

Hein, G. E. (1998). Learning in the museum. London: Routledge

Hein, G. E. (Septemer 24, 2001). Informal science supporting education reform: Theory and practise / beliefs and actions. Lecture delivered at the Fifth Annual Northeast Informal Science Education Network Conference, Worcester, MA.

Hofstein, A. \& Rosenfeld, S. (1996). Bridging the gap between formal and informal science learning. Studies in Science Education, 28, 87-112.

Institute of Museum and Library Services (2002). True needs, true partners: Museums serving schools. Washington, DC, Institute of Museum and Library Services.

Inverness Research Associates (1996). An invisible infrastructure: Institutions of informal science education. Washington, DC: Association of Science-Technology Centres.

King, K. (1998). Alternative educational systems: A multi-case study in museum schools. Unpublished doctoral dissertation, Indiana University.

Klein, C., Corse, J., Grigsby, V., Hardin, S. \& Ward, C. (2001, April). A museum school: Building grounded theory as two cultures meet. Paper presented at the annual meeting of the American Educational Research Association, Seattle, WA.

Melber, L. M., \& Cox-Petersen, A. M. (2005). Teacher professional development in informal learning environments: Investigating partnerships and possibilities. Journal of Science Teacher Education, 16, 103-120.

Meyer, H. (2004). Novice and expert teachers' conceptions of learners' prior knowledge. Science Education(88), 1-14.

NRC. (1999). How people learn: Brain, mind, experience and school. Washington, DC: National Academy Press. 


\section{M.L. Phillips et al.}

NRC. (2000). Inquiry and the national science education standards: A guide for teaching and learning. Washington, DC: National Academy Press.

Olson, J. K., Cox-Peterson, A. M., \& McComas, W. F. (2001). The inclusion of informal environments in science teacher preparation. Journal of Science Teacher Education, 12(3), 155-173.

Ramey-Gassert, L., Walberg, H. J. I., \& Walberg, H. J. (1994). Reexamining connections: Museums as science learning environments. Science Education, 78(4), 345-363.

Rennie, L.J., Feher, E., Dierking, L.D. \& Falk, J. H. (2003). Toward an agenda for advancing research on science learning in out-of-school settings. Journal of Research in Science Teaching, 40 (2), 112-120.

Scribner, S. \& Cole, M. (1973) Cognitive consequences of formal and informal education. Science, 182(4112), pp. 553-559

Thompson, C.L., \& Zeuli, J.S. (1999). The frame and the tapestry: Standards-based reform and professional development. In L. Darling-Hammond \& G. Sykes (Eds.), Teaching as a learning profession: Handbook of policy and practice (pp. 341-375). San Francisco: Jossey-Bass.

van Driel, J.H., Verloop, N., \& de Vos, W. (1998). Developing science teachers' pedagogical content knowledge. Journal of Research in Science Teaching, 35(6), 673-695.

Windschitl, M. (2004). Folk theories of "inquiry": How preservice teachers reproduce the discourse and practices of an atheoretical scientific method. Journal of Research in Science Teaching, 41(5), 481512. 